Abbreviated Key Title: Sch J Med Case Rep

ISSN 2347-9507 (Print) | ISSN 2347-6559 (Online)

Journal homepage: https://saspublishers.com

\title{
Pilomatrixoma - Incidental Diagnosis by Fine Needle Aspiration Cytology
} Debaditya Samanta ${ }^{1}$, S M Sarfaraj ${ }^{1 *}$, Soumya Dey ${ }^{1}$, Chhanda Datta ${ }^{2}$, Asim Kumar Manna ${ }^{2}$

${ }^{1}$ Post Graduate Trainee, ${ }^{2}$ Professor, Department of Pathology, Institute of Post Graduate Medical Education \&Research, Kolkata India

DOI: $10.36347 /$ sjmcr.2021.v09i02.014

| Received: 09.02.2021 | Accepted: 22.02.2021 | Published: 24.02.2021

*Corresponding author: S M Sarfaraj

Abstract

Case Report

Pilomatrixoma or calcified epithelioma of Malherbe is a tumour with differentiation toward hair cells. The face and the upper extremities are the most common sites with an exception at cubital fossa region [1]. Here we present a case of a middle-aged man came with complaint of a swelling at left arm for 3-4 years. On fine needle aspiration cytology, it showed clump of anucleate keratinized squamous cells, small basaloid cells and inflammatory cells. We made a provisional diagnosis of pilomatrixoma which was later confirmed Histopathologically.

Keywords: Pilomatrixoma epithelioma Histopathologically.

Copyright $\odot 2021$ The Author(s): This is an open-access article distributed under the terms of the Creative Commons Attribution 4.0 International License (CC BY-NC 4.0) which permits unrestricted use, distribution, and reproduction in any medium for non-commercial use provided the original author and source are credited.

\section{INTRODUCTION}

Pilomatrixoma are relatively uncommon, benign tumours arising from skin adnexa. Despite being better defined, pilomatrixomas continue to be misdiagnosed and are not usually included in the differential diagnosis [2]. It frequently presents as a firm nodule covered by normal skin. Generally, it varies in diameter from 0.5 to $3 \mathrm{~cm}$, but it may be as large as 5 $\mathrm{cm}$. $40 \%$ of them arise in children younger than 10 years of age and rest are seen in first two decades of life [1]. Diagnosis is made by histological examination usually.

\section{CASE Report}

48 years old male presented with complaint of a hard swelling over left cubital fossa with history of gradual increase in size.The swelling was painless. Clinicians provisionally diagnosed it as calcified neurofibroma. Fine needle aspiration was done and the hyper cellular smear showed large number of clustered basaloid cells with scanty cytoplasm and medium-sized, hyperchromatic, mildly irregular nuclei. Aggregates of degenerate, anucleate keratinized squamous cells also seen. Calcium granules and debris was present [Fig 1]. On the basis of cytomorphological features, a provisional diagnosis of pilomatrixoma was made. Excision of the swelling was done later on.

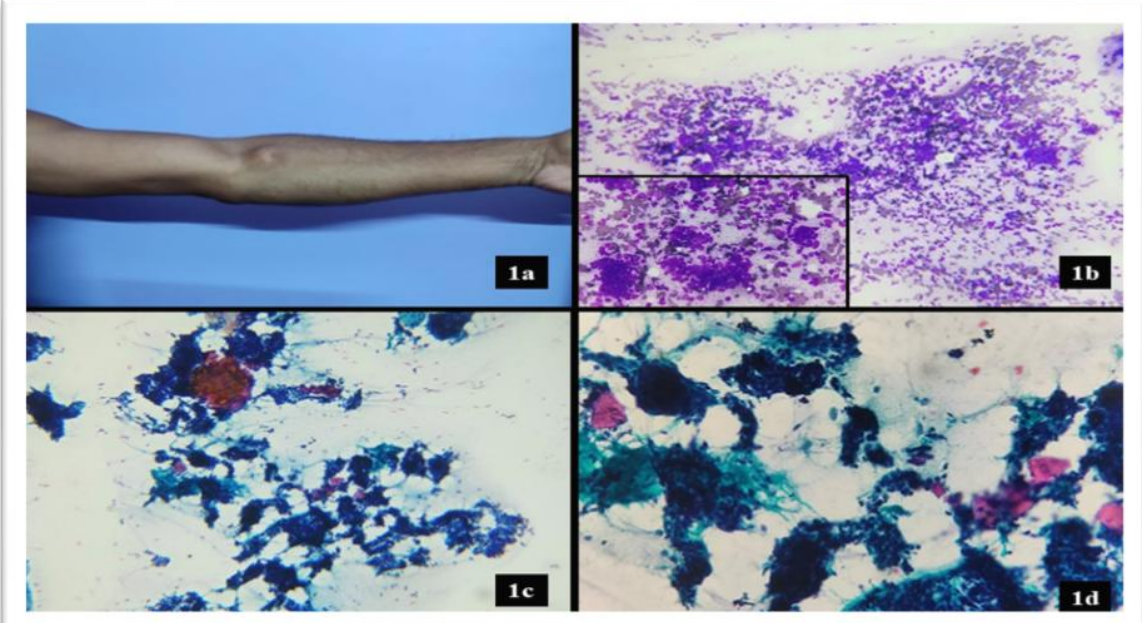

Fig-1: a) Nodular hard swelling over left cubital fossa. b) Aggregates of basaloid cells (x100, MGG), inset shows high power view of the same (x400, MGG) c) Anucleate keratinocytes and calcium debris (x100, PAP) d) Anucleate keratinocytes (x400, PAP) 
On histology it was a tumour mass composed of solid nests of small basaloid cells with presence of anucleate ghost cells and abrupt keratinization. Tumour cells were PAS stain positive. These findings validated the provisional diagnosis of pilomatrixoma.

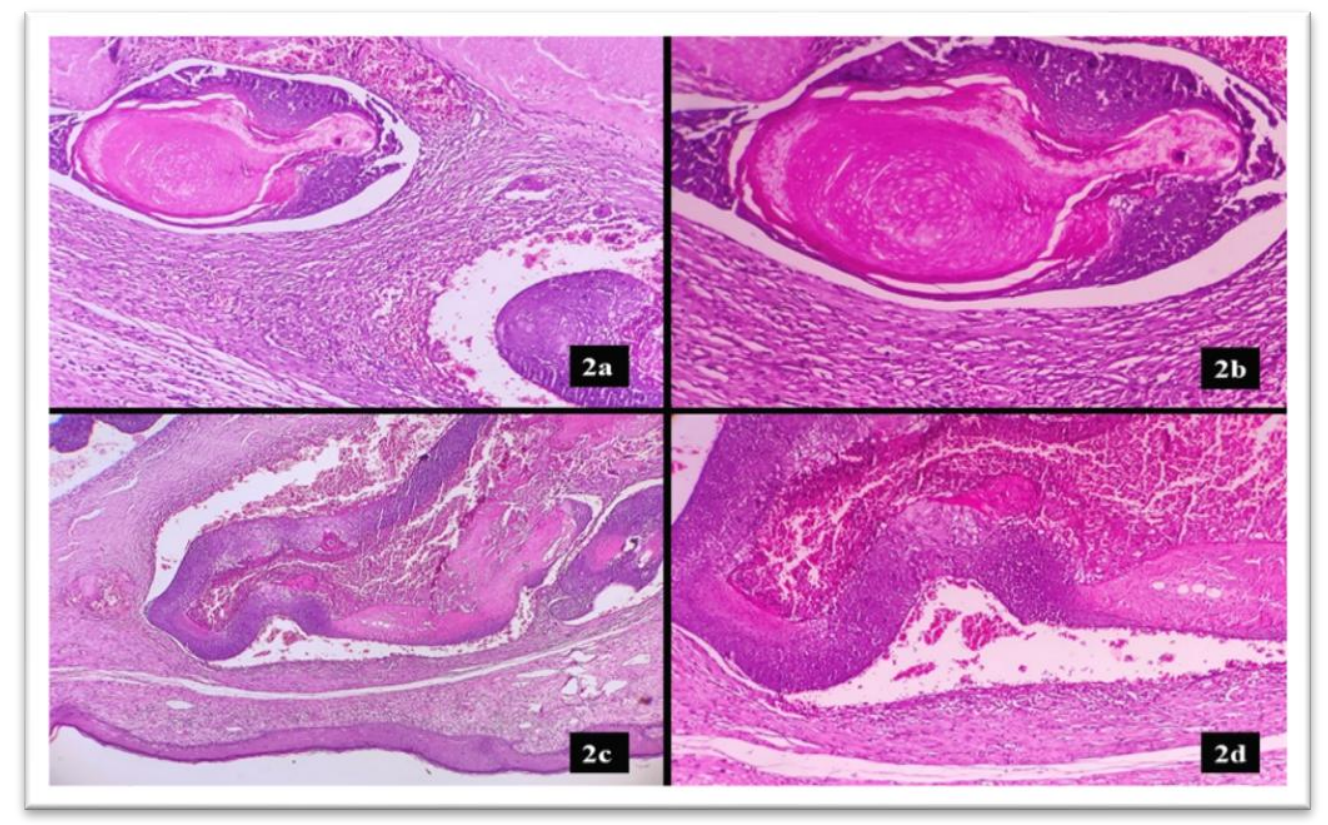

Fig-2: a) Histology showing nest of basaloid cells along with abrupt keratinisation and ghost cells $(x 100, H \&$ E) b) High power view of the same $(\mathrm{x} 400, \mathrm{H} \& \mathrm{E})$ c) and d) showing another area with similar features in low power and high power respectively $(\mathrm{x} 100 \& \mathrm{x} 400, \mathrm{H} \& \mathrm{E})$

\section{DISCUSSION}

Pilomatrixoma is a nodular, benign tumour arising from the hair matrix [3]. It frequently presents as a firm, deep seated nodule that is covered by normal skin. Occasionally, however, the tumour is more superficially located; causing a blue-red discolouration of overlying skin and rarely it protrudes as a sharply demarcated dark red nodule. Rapid enlargement can occur as a result of formation of haematoma [1]. Radiological imaging is of limited use as it shows only variable amount of calcification. Fine needle aspiration is useful in preoperative diagnosis. Presence of ghost cell a must for the diagnosis [2]. Tightly bound basaloid cells are seen [4]. The cytological features of pilomatrixoma are characteristic and allow a conclusive diagnosis provided the smears are examined keenly bearing in mind the diagnostic traps that can mislead a cyto-pathologist [5]. Histological features shows epithelial islands embedded in cellular stroma. Two types of cells comprise the island: basophilic basaloid cells and anucleate ghost cells. There are calcified areas also [1]. Only a few cases of malignant transformation of pilomatrixoma have been reported till date. Treatment of choice is wide local excision with 1 to 2 $\mathrm{cm}$ of healthy skin margins toattenuate the danger of local recurrence. The reported risk of recurrence after surgery is $0 \%$ to $3 \%$ in most of the series. Repeated recurrence is indication of malignant transformation [6].

\section{CONCLUSION}

To summarize, pilomatrixoma is an asymptomatic, slow growing, firm, non-tender and benign skin tumour that originates from hair follicle matrix cells and is mainly present in children and young adults. With all these clinical features, morphological, cytological and histological findings, diagnosis of pilomatrixoma in a sub-cutaneous swelling should always be considered.

\section{REFERENCES}

1. David E Edler. Tumours of epidermal appendages. In Lever's Histopathology of Skin, $10^{\text {th }}$ edition. Lippincott Williams. 2009; 864-865.

2. Pavneet K Sethi, Puneet Singla, Vikram Narang, Harpeet Puri. Pilomatrixoma: diagnosed by fine needle aspiration cytology. Indian $\mathrm{J}$ of Dermatopath and Diag Dermat. 2014;1(1):45-46.

3. John R Goldblum, Jesse K McKenney. Tumours and tumour like condition in skin. In Rosai and Ackerman's Surgical Pathology. $11^{\text {th }}$ edition. Elsevier. 2019; 67.

4. Svante Orell, Gregory F. Sterrett. Skin and subcutis. In Orell and Sterrett's Fine needle aspiration cytology. $5^{\text {th }}$ edition. Churchill Livingstone. 2005; 374-376.

5. Cherry Bansal, Uma Handa, Harsh Mohan. Fine needle aspiration cytology of pilomatrixoma. J Cytol.2011; 28(1):1-6.

6. Forbis R Jr, Helwig EB. Pilomatrixoma. Arch Dermatol. 1961; 83:606-18. 